\title{
La antropología americanista española y la identidad nacional: el debate entre Juan Comas y José Pérez de Barradas (1949-1953) ${ }^{1}$
}

No es fácil construir una identidad nacional cuando hay varios discursos identitarios compitiendo entre sí, y en igualdad de condiciones. Siendo la historia un campo privilegiado para la construcción de identidades nacionales, la controversia en España sobre la conquista de América es una expresión -como otras de las que se ha hecho eco la prensa en los últimos meses ${ }^{2}$ - de esta competencia entre discursos. Tema ya polémico en su momento, e ingrediente básico en la llamada "leyenda negra" difundida por Europa desde el siglo XVI, la Conquista ha aparecido con frecuencia en las discusiones sobre España como nación en el propio país,

1 El presente artículo es un resultado del proyecto Antropología, política y colonialismo en los Estados franquista y salazarista (DGICYT PS93-0001), dirigido por Carmen Ortiz, quien fue la que llamó mi atención sobre la relevancia del debate entre Comas y Pérez de Barradas. Presenté una primera versión del texto en el XVII Curso de Etnología Española "Julio Caro Baroja", Historia y actualidad de la antropología en España (Madrid, del 1 al 29 de abril de 1997), donde fue comentada, además de por Carmen Ortiz, por Fermín del Pino Díaz, Luis Díaz G. Viana y otros asistentes, a quienes deseo expresar aquí mi agradecimiento por sus sugerencias. Una segunda versión fue debatida en una mesa redonda organizada por la Escuela de Estudios Hispano-Americanos del CSIC, en Sevilla (10 de marzo de 1998), en la que participaron, entre otros, Enriqueta Vila, Berta Ares, Javier Ortiz de la Tabla, Jaime del Arenal, José Jesús Hernández Palomo y Juan Martín, cuyos comentarios también contribuyeron a mejorar una argumentación que era y es de mi exclusiva responsabilidad.

2 Por ejemplo, las historias de las diferentes nacionalidades y regiones en que está hoy dividido el Estado español, especialmente las historias de Cataluña y el País Vasco, entendidas como ajenas o contradictorias con la historia de España (El País, 2 de noviembre de 1997). En los últimos meses, el proyecto del Gobierno del Partido Popular de asegurar en todo el Estado la enseñanza de una historia común de España dentro del plan de estudios en humanidades en la Enseñanza Secundaria Obligatoria, con independencia de la enseñanza de la historia de cada una de las nacionalidades y regiones en sus respectivos territorios, ha sido derrotado en el Congreso de los Diputados por la oposición de los demás partidos políticos, incluidos los de ámbito estatal (El País, 12 de noviembre de 1997). El hecho ha puesto de manifiesto la existencia de un conflicto entre diferentes versiones de la historia de España, aparte del conflicto con las historias de ciertas nacionalidades y regiones. 
reveladoras de lo raro que aquí es no sentirse aludido por referencias a hechos del pasado, especialmente ante acontecimientos de dimensiones internacionales ${ }^{3}$. Así, algunos pensadores liberales del siglo XIX, como Juan Antonio Llorente o Manuel José Quintana, enemigos del absolutismo del Antiguo Régimen, saludaron la rebelión de las provincias americanas apelando al testimonio de Bartolomé de Las Casas para recordar los abusos cometidos por los conquistadores ${ }^{4}$. En la segunda mitad del siglo, el interés por las causas y remedios a la decadencia española llevó a autores como Fernando de Castro ${ }^{5}$ o Antonio Cánovas del Castillo ${ }^{6}$ a valorar la Conquista como uno de los mayores logros alcanzados nunca por los españoles, en tanto que el periodo subsiguiente, el del imperio colonial americano, había sido el del origen de la decadencia, al significar la consolidación de una monarquía autoritaria y belicista, el triunfo del fanatismo religioso y el sostenimiento del Imperio a expensas del desarrollo nacional. Una España nueva debía tomar como modelo la situación protodemocrática, tolerante y próspera de los reinos peninsulares en la Baja Edad Media.

Años más tarde, tras la crisis de 1898 y con ocasión de la campaña internacional de protesta por la represión de los sucesos de la Semana Trágica en Barcelona —que incluía abundantes referencias a los hechos de los conquistadores-, Julián Juderías escribió que esa campaña se explicaba por la envidia secular a España y su pasado glorioso; los hechos referidos no tenían otra verdad que ésa ${ }^{7}$. La principal fuente de la leyenda negra, los escritos de Bartolomé de Las Casas contra la Conquista y en defensa de las sociedades precolombinas, ya había sido desautorizada por Marcos Jiménez de la Espada en $1892^{\circ}$, como lo sería por Ramón

3 Fenómeno éste ya denunciado por Julio CARO BAROja hace cerca de treinta años como mero ejercicio de mitología: El mito del carácter nacional. Meditaciones a contrapelo (Madrid: Seminarios y Ediciones, 1970).

4 Juan Antonio Llorente, Oeuvres de don Barthélemi de Las Casas, évéque de Chiapa, defenseur de la liberté des naturels de l'Amérique: précedés de sa vie et accompagnées de notes historiques, additions, développements... (Paris: Alexis Eymery, Librairie-Editeur, 1822). Manuel José QuinTANA, Fray Bartolomé de Las Casas (Buenos Aires: Editorial Poseidón, 1943) (publicada por primera vez en 1833).

5 Los caracteres bistóricos de la Iglesia española (Madrid: M. Rivadeneyra, 1866).

6 Historia de la decadencia de España desde el advenimiento de Felipe III al trono basta la muerte de Carlos II (Madrid: J. Ruiz Editor, 1910), 2." ed. La primera edición es de 1854 .

7 La leyenda negra (Madrid: Swan Editor, 1986). La primera edición es de 1914.

8 "Prólogo" a De las antiguas gentes del Perí, de fray Bartolomé de Las Casas (Madrid: Colección de Libros Españoles Raros o Curiosos, Vol. 21, 1892). 
Ménendez Pidal en 1957 y $1963^{\circ}$. Otros autores, como Azorín ${ }^{10}$ o Ramiro de Maeztu ${ }^{11}$, señalaron al siglo XVI, y no a la Edad Media, como la época de plenitud, la de la España cristiana, para ellos la auténtica, desconocedora aún de la Ilustración, el liberalismo y otros factores reales de decadencia.

En los últimos años, los actos oficiales organizados en conmemoración del V Centenario del primer viaje de Cristóbal Colón —en el contexto de una España que busca una posición relevante en la Unión Europea-, han dado ocasión a la forma más reciente de esta polémica. Presentado el famoso viaje como un hito en la historia de los descubrimientos de la humanidad, en aras de una visión aséptica que ahuyentara el debate sobre las consecuencias de todo orden que se derivaron del acontecimiento ${ }^{12}$, la conmemoración ha ocasionado, paradójicamente, la aparición de varios ensayos críticos sobre el sentido que tienen para la España actual los hechos conmemorados. Los ensayos de Antonio Acosta ${ }^{13}$, Rafael Sánchez Ferlosio ${ }^{14}$ y Eduardo Subirats ${ }^{15}$ han sido especialmente duros contra todo nuevo intento de reivindicación de la España imperial. Acosta ha lamentado que se usara la historia de América como pretexto para impulsar intereses locales o nacionales -especialmente económicos-, ajenos a las necesidades de la mayoría de la población americana.

9 Una norma anormal del Padre Las Casas (Madrid: Gráficas Valera, 1957); El Padre Las Casas. Su doble personalidad (Madrid: Editorial Espasa Calpe, 1963).

10 "Una hora de España (entre 1560 y 1590)", discurso de ingreso en la Real Academia Española, en 1924, publicado en Obras Completas (Madrid: Aguilar, 1948), Vol. IV, pp. 536-537.

11 Defensa de la bispanidad (Madrid: Gráficas González, 1946). La primera edición es de 1935

12 Sirva de muestra el documental Los descubridores, de Greg MacGillivray, producido para la Exposición Universal celebrada en Sevilla desde abril a octubre de 1992; aún se puede ver en el cine Omnimax de la isla de la Cartuja, donde tuvo lugar la exposición. En el programa de la película se lee lo siguiente: "Con ella navegaremos por los mares con Fernando de Magallanes en busca del mar del Sur, volaremos sobre la superficie de Venus con científicos de hoy día, seremos testigos del descubrimiento de pinturas rupestres en Altamira, nadaremos al lado de delfines y estudiaremos su inteligencia, descubriremos con Newton los efectos de la luz y además viajaremos al Polo Norte a presenciar una aurora borealn.

13 "América Latina: Historia y pretexto (el '92 una operación en marcha)". Boletín Americanista, 37 (1987), pp. 5-17.

14 Esas Yndias equivocadas y malditas. Comentarios a la bistoria (Barcelona: Ediciones Destino, 1994).

15 El continente vacio. La conquista del Nuevo Mundo y la conciencia moderna (Madrid: Anaya \& Mario Muchnik, 1994). 
Sánchez Ferlosio ha recordado las atrocidades cometidas durante la Conquista; por otra parte inexorables, según él, dados los parámetros de la civilización europea. Subirats ha llamado la atención sobre las limitaciones políticas e ideológicas de aquellos que las denunciaron en el siglo XVI, como Bartolomé de Las Casas o Francisco de Vitoria. Su perspectiva recuerda los argumentos indigenistas de los años 30 y 40, como ha advertido Castilla Urbano ${ }^{16}$. El propio Subirats se ha declarado seguidor de Américo Castro en su famoso debate con Claudio Sánchez Albornoz sobre España y los españoles ${ }^{17}$.

Más comprensivos con los actos de conmemoración han sido Xavier Rubert de Ventós ${ }^{18}$ y Fermín del Pino Díaz ${ }^{19}$. El primero ha comparado favorablemente la experiencia española en América con la de Gran Bretaña y los Estados Unidos, destacando el pensamiento antropológico y jurídico que generó, la legislación de la Corona a favor de la población aborigen y el interés de proyectos político-misionales como los de los jesuitas. Pino Díaz ha advertido contra los riesgos de juzgar el pasado desde las preocupaciones del presente, considerando "curioso que sean los intelectuales españoles los más críticos con el pasado colonial hispano en América: porque en Europa y América muchos otros consideran legítimo que un país reclame como prestigioso el pasado colonial presentado, al menos parcialmente, en tanto conquista técnica del espacio ${ }^{20}$ o desencadenante de una abundante literatura histórica y de ficción. Y ello por no hablar de tópicos como el progresivo poblamiento urbano, la instalación de colegios y universidades, la protección a las relaciones geográficas y a las expediciones científicas, etc.".

Julián Marías ${ }^{21}$ ha resaltado la importancia del mestizaje en la América española y portuguesa, origen de la "Comunidad Hispánica de Naciones", relevante en el complejo concierto internacional de hoy; de los actos de conmemoración ha censurado "la resonancia y alcance [dados] a la

16 Francisco Castilla Urbano, "Reseña bibliográfica de El continente vacío, de Eduardo Subirats", Revista de Indias, 203 (1995), pp. 264-268.

17 Américo Castro, España en su bistoria. Cristianos, moros y judios (Buenos Aires: Talleres Gráficos de Sebastián de Amorrortu e Hijos, 1948). Claudio SÁNCHEZ ALBORNOZ, España, un enigma bistórico (Buenos Aires: Editorial Sudamericana, 1956).

18 El laberinto de la bispanidad (Barcelona: Editorial Planeta, 1987).

19 "Los antropólogos españoles y el V Centenario", Antropología, 1 (1991), pp. 108-114.

20 Énfasis de Pino Díaz.

${ }^{21}$ La Corona y la Comunidad Hispánica de Naciones (Madrid: Asociación Francisco López de Gómara, 1992). 
acción de grupos mínimos y de extremada pobreza intelectual que pretenden desprestigiar uno de los episodios más fecundos y creadores de la historia, que han contribuido acaso más que ningún otro al enriquecimento del mundo entero" ${ }^{22}$. Juan Luis Beceiro García ha refutado la tesis del genocidio español en América, en respuesta a las protestas de las organizaciones indígenas del continente por la conmemoración ${ }^{23}$. Lamentando que no hubiera otro que las contestara, se preguntaba: “¿Dónde está el patriotismo (sentir a España), ahora, que por no pronunciar la palabra 'España' dicen 'Estado Español', 'Este País' o 'Estado' simplemente? Y no son unos pocos, lo son casi todos en el Gobierno, en Las Cortes, en las Instituciones más diversas, en la prensa, radio y televisiones" ${ }^{24}$.

Entre 1949 y 1953, una versión anterior de esta controversia, menos conocida, protagonizada por Juan Comas y José Pérez de Barradas, se desenvolvió en términos parecidos. Aparte de ilustrar sobre los recursos conceptuales con que se contaba en la época, tuvo la peculiaridad de enfrentar a dos antropólogos americanistas afectados por la guerra civil. El motivo fue la reivindicación, por parte de la dictadura de Franco, de la idea nacional de España que ya habían defendido Ramiro de Maeztu en 1935, Azorín en 1924 y Juderías en 1914; idea que a su vez estaba en la línea del pensamiento de algunos autores regeneracionistas (como Ángel Ganivet ${ }^{25}$ ) y en la de representantes del nacionalismo católico del siglo XIX, como Marcelino Menéndez y Pelayo ${ }^{26}$. También se nutría de la posición "hispanista" que intelectuales mejicanos y peruanos oponían desde 1930 al indigenismo, en el debate sobre la identidad nacional de sus respectivos países ${ }^{27}$. Contrariamente a lo sucedido en Portugal bajo la dic-

22 La Corona..., p. 125.

23 La mentira bistórica desvelada. ¿Genocidio en América? Ensayo sobre la acción de España en el Nuevo Mundo (Madrid: edición del propio autor con la colaboración de la Xunta de Galicia, 1994).

24 La mentira bistórica..., p. 19. Énfasis del autor.

25 Idearium español (Madrid: Editorial Biblioteca Nueva, 1996). La primera edición es de 1897.

26 La ciencia española (Santander: Aldus S. A. de Artes Gráficas, 1953), edición en 3 Vols. preparada por Enrique Sánchez Reyes (textos publicados por primera vez entre 1876 y 1888). "Prólogo" a Antología de poetas líricos castellanos (de 1888 a 1908). edición en 5 Vols. preparada por Enrique Sánchez Reyes, Vol. 1, pp. 3-33 (Madrid: Aldus S. A. de Artes Gráficas, 1954). Historia de los beterodoxos españoles: erasmistas y protestantes, sectas místicas, judaizantes y moriscos, artes mágicas (Ciudad de Méjico: Editorial Porrúa, 1982) (primera edición en 1882).

27 En Perú, Víctor Andrés Belaúnde y José de la Riva-Agüero en sus obras de los años 30 y 40 (v. g., La crisis presente, Afirmación del Perí, respectivamente) frente a 
tadura de Oliveira Salazar, cuando el régimen propició el estudio antropológico de las colonias como medio de promover su proyecto nacionalista, el gobierno de Franco recurrió para este fin principalmente a la propagación de esa idea nacional de España y los españoles, con su pasado imperial, añadiéndole el interés por las teorías raciales del siglo XIX y por la ideología nacional-socialista de los años 30. El Gobierno contó para ello con el apoyo de historiadores y antropólogos como Pérez de Barradas, encumbrado en los años posteriores a la guerra civil a posiciones académicas de gran importancia. En 1949 era director del Museo Etnológico y del Instituto Bernardino de Sahagún del CSIC, así como catedrático de antropología en la Universidad de Madrid. Hasta 1944 también había sido director del Museo del Pueblo Español ${ }^{28}$. Comas debatió con él desde el exilio en Méjico, como secretario del Instituto Indigenista Interamericano y su órgano América Indígena, y también como director del Boletín Bibliográfico de Antropología Americana ${ }^{29}$.

autores como José Carlos Mariátegui y Luis Valcárcel. En Méjico, como me ha señalado Jaime del Arenal, los hispanistas Carlos Pereyra (Hernán Cortés; Méjico falsificado) y Toribio Esquivel Obregón (El indio en la bistoria de México; En defensa de la cultura bispánica) frente a indigenistas como Alfonso Caso, Miguel Othón de Mendizábal y Luis Chávez Orozco, entre otros autores.

28 Luis Ángel SÁNCHEz GÓMEZ, "La antropología al servicio del Estado: el Instituto 'Bernardino de Sahagún' del CSIC (1941-1970)», RDTP, XLVII (1992), pp. 29-44. Pérez de Barradas había nacido en 1897, en Cádiz. Sobre su vida, véase Carmen OrTiz y Luis Ángel SÁNCHez GÓMEz (eds.), Diccionario bistórico de la antropología española (Madrid: CSIC, 1994), pp. 548-551. Pérez de Barradas llegó a la antropología desde las ciencias naturales y la arqueología. La guerra civil le había sorprendido en Colombia, donde llevó a cabo diversos proyectos arqueológicos y etnográficos, origen de varias publicaciones: Colombia de norte a sur (Madrid, 1943), Arqueología agustiniana (Bogotá, 1943), Los muiscas antes de la conquista del reino de Nueva Granada (Madrid, 1950-1951) y "Drogas ilusionógenas de los indios americanos", Antropología y Etnología III (1950), pp. 9-107, entre otras.

29 Para la biografía de Comas, véase Carmen OrTiz y Luis Ángel SáNCHEZ GÓMEZ, Diccionario..., pp. 208-214. Comas había nacido en Alayor (Menorca) en 1900. Era hijo de un maestro y se educó en la Escuela de Magisterio de Madrid, donde fue discípulo de Luis de Hoyos Sáinz, uno de los primeros antropólogos españoles en la historia académica de la disciplina. Salido de la Escuela, Comas trabajó como inspector de Primera Enseñanza y en 1928 obtuvo una beca de ampliación de estudios para estudiar antropología física en Ginebra bajo la dirección de Eugène Pittard. Su tesis doctoral, Contribution à l'étude du metopisme, la defendió en 1939, camino del exilio. Durante los años de la II República y la guerra civil, había sido secretario de la Junta de Relaciones Culturales del Ministerio de Estado y secretario de la Dirección General de Primera Enseñanza. 


\section{EL "NACIONALISMO LIBERAL" Y LA CONQUISTA DE AMÉRICA}

En un reciente ensayo sobre la historia del nacionalismo español, a propósito de la creciente contestación a la identidad nacional de España ${ }^{30}$, E. Inman Fox ha sostenido que en esa historia del nacionalismo, contra lo que pudiera parecer, es el nacionalismo liberal el que ha dominado, no el nacionalcatolicismo y menos aún los nacionalismos vasco y catalán. El nacionalismo liberal surgió a mediados del siglo pasado y a partir de 1890 lo impulsaron vigorosamente los regeneracionistas y el Centro de Estudios Históricos de Menéndez Pidal. Sus promotores construyeron una idea de la cultura nacional española y el carácter de los españoles con materiales tomados de la literatura, el folklore, la pintura y otros géneros artísticos; y su planteamiento político, basado en la correspondiente interpretación de la historia de España, era que el Estado adecuado para la nación "sería de índole democrático-liberal" ${ }^{31}$. En buena medi$\mathrm{da}$, este nacionalismo seguiría vigente todavía hoy.

Sin embargo, tal concepto de nacionalismo liberal, incluye demasiados elementos heterogéneos, que sólo tienen en común el no formar parte de la tradición nacionalista católica ni de otros nacionalismos peninsulares. Fox no distingue lo suficiente el movimiento regeneracionista del pensamiento liberal anterior. Para él son meras etapas de un mismo fenómeno en crecimiento, como si los años del agotamiento del régimen constitucional de 1876 y la crisis de 1898 (los años de un renovado interés por América, paralelo a la creciente emigración española hacia el otro lado del Atlántico y los sucesos de Cuba y Filipinas) fueran homologables a los de las luchas revolucionarias de las décadas precedentes, cuando aún se recordaba el absolutismo del Antiguo Régimen y se pensaba que la época mejor de España había sido la Baja Edad Media, no la monarquía imperial de los Austrias y los Borbones. Dentro del regeneracionismo, Fox tampoco diferencia lo suficiente a autores tan políticamente divergentes como Ganivet —contrario a la democracia-, Unamuno - próximo al socialismo por los mismos años- y Luis Morote, un federalista valenciano que añoraba la España plural de reinos y municipalidades de los Reyes Católicos ${ }^{32}$. Asimismo es necesario distinguir claramente entre el regenera-

${ }^{30}$ La invención de España. Nacionalismo liberal e identidad nacional (Madrid: Cátedra, 1997).

31 La invención..., pp. 11-14, 201-205.

32 La moral de la derrota (Madrid: Biblioteca Nueva, 1997). La primera edición es de 1900 . 
cionismo y los pensadores de la generación de 1914, y después entre estos mismos: Julián Juderías y su reivindicación de la España imperial; el europeísta José Ortega y Gasset y su "nuevo liberalismo", denunciado por Unamuno como un proyecto antidemocrático ${ }^{33}$; y Manuel Azaña y su crítica a Ganivet y otros representantes del "regeneracionismo dictatorial" ${ }^{34}$. Todo ello, sin entrar en el tema de la evolución de cada uno de estos autores.

Hechas estas distinciones, la sensación que emerge es la de una gran pluralidad de discursos que difícilmente cabe considerar como expresiones de un nacionalismo liberal, menos aún un nacionalismo liberal dominante. Cabe asimismo dudar de su supervivencia hasta hoy, dado el creciente interés en la variabilidad étnica de España a expensas de la idea de una cultura nacional ${ }^{35}$. El mismo Fox reconoce que el concepto de nación española en el sentido "cívico" de la expresión —el más acorde con un Estado que "sería de índole democrático-liberal" ${ }^{36}$ - ha tenido poco éxito en España. Las diversas valoraciones sobre la conquista de América complican aún más esta situación. Liberales como Juan Antonio Llorente y Manuel José Quintana tenían una opinión sobre Bartolomé de Las Casas radicalmente diferente de la de los igualmente liberales Jiménez de la Espada y Menéndez Pidal; y es que unos y otros tenían ideas diferentes de España como nación. El debate entre Comas y Pérez de Barradas, más allá del marco científico de la discusión, mostró el mismo marco dialéctico: el de un conflicto identitario sobre España que se remontaba al siglo XIX, en el que se discutía sobre su unidad, sobre el sistema político adecuado, sobre las lecciones del pasado al respecto, y sobre otros países, que eran precisamente aquellos en donde más se había difundido la leyenda negra. En ese marco dialéctico, que también se adivina en la controversia sobre la conmemoración del V Centenario del viaje de Colón, se ubicaba el debate sobre el testimonio de Bartolomé de Las Casas y otros críticos de la Conquista; sobre la situación de la población aborigen antes y después de 1492; sobre el racismo y el indigenismo; y sobre el mestizaje y el balance histórico de una experiencia que duró más de tres siglos.

33 "Partidos de papel", en El liberal, de Bilbao, edición del 4 de enero de 1924; citado por E. I. Fox, La invención..., p. 178.

34 E. I. Fox, La invención..., pp. 131, 178.

35 Encarnación Aguilar CRIADO, "De la construcción de la historia a la práctica de la antropología, en E. AGUilar CRIADo (coord.), De la construcción de la bistoria a la práctica de la antropología en España (Zaragoza: Instituto Aragonés de Antropología y Federación de Asociaciones de Antropología del Estado Español, 1996), pp. 11-19.

36 El prototipo es la república francesa. La definición es de Anthony D. SMITH, "Tres conceptos de nación", Revista de Occidente, 161 (1994), pp. 7-22. 


\section{UNIDAD RACIAL Y UNIDAD POLÍTICA}

El debate surgió al comentar Comas el libro de Pérez de Barradas, Manual de antropología ${ }^{37}$, en sendas reseñas para la revista Ciencia y para Actas y Memorias de la Sociedad Española de Antropología, Etnografía y Prebistoria, en $1949^{38}$. Dos años después publicó una serie de tres artículos para América Indígena ${ }^{39}$, criticando el libro del jesuita Constantino Bayle, El Protector de Indios ${ }^{40}$, y el de Pérez de Barradas, Los mestizos de América ${ }^{41}$.

El Manual de Pérez de Barradas, nacido de la preparación de sus clases en la universidad, consagraba 460 de sus 524 páginas a "Antropología física", "Antropología fisiológica" y "Paleontología humana". El resto era el material "etnológico", bajo el título "Raciología o Antropología descriptiva", en donde Pérez de Barradas hablaba de los tipos raciales en España y el resto del mundo, confundiendo el concepto de raza con el de cultura y considerando el mestizaje como perjudicial para las virtudes de las razas. Este gran interés en temas de antropología física, a costa de los etnológicos, representaba una ruptura con el contenido de manuales anteriores - por ejemplo, el de Luis de Hoyos y Telesforo Aranzadi, Lecciones de Antropología, de 1899-1900-, más equilibrados y originales ${ }^{42}$. Como advertiría Comas, Pérez de Barradas escribió en el suyo que, en España, la existencia de distintos tipos raciales era más aparente que real; la situación era, por el contrario, de "homogeneidad racial" ${ }^{43}$. En América, sin embargo, como en otros continentes, lo característico era la diversidad de tipos, si bien no había significativas diferencias evolutivas entre ellos, incluidos los responsables de las que entonces y hoy se consideran las tres grandes

37 Madrid: Cultura Clásica y Moderna, 1946.

38 "Reseña de Manual de Antropología, de José Pérez de Barradas", Ciencia, 8 (1949), pp. 277-278; Actas y Memorias de la Sociedad Española de Antropología, Etnografia y Prebistoria, 24 (1949), pp. 104-109.

39 "Reivindicación del indio y lo indio", América Indígena, XI, 2 (1951), pp. 129146. "La 'cristianización' y 'educación' del indio desde 1492 a nuestros días", América Indigena, XI, 3 (1951), pp. 219-234. "La realidad del trato dado a los indígenas de América entre los siglos XV y xx”, América Indígena, XI, 4 (1951), pp. 323-370.

40 Sevilla, Escuela de Estudios Hispano-Americanos, 1945.

41 Madrid: Cultura Clásica y Moderna, 1948.

42 Carmen ORTIZ, "La antropología española en el primer tercio del siglo XX: líneas de continuidad y ruptura", E. AGUILAR CRIADO (coord.), De la construcción de la bistoria..., op. cit., pp. 124-126.

43 José PÉrez DE BARRAdas, Manual..., p. iv. 
civilizaciones precolombinas: aztecas, mayas e incas. Pérez de Barradas puso así a los aztecas al lado de los chichimecas, pueblo nómada del norte de Méjico que vivía de la caza y los frutos silvestres. De los nahuas, el pueblo matriz, comentó que estaban ahoy degenerados por los mestizajes". De los mayas señaló que se había "exagerado su antigüedad y su grado de adelanton; y de los incas, tan sólo que eran la clase dirigente de los quechuas, "el grupo indígena principal" en los Andes ${ }^{44}$.

Comas censuró del Manual su concepto del mestizaje, que nacía de una confusión entre lo que era la herencia genética y la eugenesia. Había otras premisas conceptuales discutibles, como las relativas a la evolución ${ }^{45}$; pero Comas dejó para sus artículos de 1951 la crítica a las afirmaciones de Pérez de Barradas sobre los pueblos indígenas americanos. Con respecto a la tesis de la homogeneidad racial en España, la entendió como una forma de justificar el Estado unitario de la dictadura de Franco. El de Pérez de Barradas era, en efecto, un argumento político disfrazado de antropología física. Pero Comas opuso otro de la misma naturaleza para sugerir un régimen político distinto; no habló de "razas" o de "tipos raciales", pero sí de "variaciones somáticas, fisiológicas y psíquicas". Reconoció así que "desde el paleolítico hasta el siglo viII es de todos conocido que la península Ibérica sufrió la invasión de los pueblos más diversos, los cuales con sus mestizajes han formado el mosaico del pueblo español que, de una a otra región, presenta variaciones somáticas, fisiológicas y psíquicas palpables". Estas "variaciones" eran las que separaban a vascos y a catalanes del resto de la población. Pérez de Barradas había confundido "la unidad política de un país y la variedad morfológica de sus habitantes" ${ }^{46}$.

\section{CONDICIÓN DE LOS ABORÍGENES AMERICANOS Y ACULTURACIÓN ESPAÑOLA}

En su obra El Protector de Indios, Constantino Bayle llamó la atención sobre esta institución del entramado judicial levantado por la Corona española en América. El Protector de Indios era la persona que intervenía en casos de abusos de indígenas por españoles; lo hacía como juez de primera instancia en causas cuya sanción no sobrepasaba los 50 pesos

44 José PÉrez DE BARradas, Manual..., pp. 494-496.

45 El Manual «es lo más malo que yo he visto nunca», le confesó Comas a su maestro Luis de Hoyos en una carta inédita de 14 de enero de 1950. Mi agradecimiento a Carmen Ortiz por haberme enseñado la correspondencia entre ambos autores.

46 Juan COMAS, "Reseña...", pp. 106. 
de oro ó 10 días de cárcel, y como abogado o fiscal — según los casosante instancias superiores cuando la sanción excediera de esa magnitud. El primer Protector fue Bartolomé de Las Casas, de quien el P. Bayle comentó que era un aimpaciente" y un "buscarruidos" ${ }^{47}$. Después ejercieron el oficio los obispos y, en la segunda mitad del siglo xvI, letrados nombrados ad boc ${ }^{48}$.

Para el P. Bayle, el Protector de Indios fue una institución de gran importancia, que sitúa a España por encima de otras potencias coloniales ${ }^{49}$. Su existencia no significaba que fuera verdad lo que aseguraba la leyenda negra; es cierto - escribió- que los españoles cometieron actos de violencia, pero "ni tanto ni tan impunes como se propala". Como la obra legisladora de la Corona y las demás instituciones indianas, la razón de ser del Protector había sido la de defender a una población aborigen que no sabía ni podía valerse por sí misma; ya que los indios eran "bobalicones aniñados", "primitivos", "bárbaros" y "brutos" "

En Los mestizos de América, Pérez de Barradas estuvo de acuerdo con esta apreciación, escribiendo que los indios eran "tristes", "perezosos", "borrachos" y dados al consumo de estupefacientes, como la coca; las crónicas de Indias ofrecían abundantes testimonios de ello. España había llevado a cabo un meritorio y completo programa de civilización, que es como Pérez de Barradas entendía la evangelización de la población aborigen y el espíritu y la letra de las leyes de Indias. La opinión contraria provenía, según él, del mito del buen salvaje y de las fantasías de Bartolomé de Las Casas ${ }^{51}$, últimamente insertados en el discurso indigenista, surgido en Iberoamérica después de la revolución mejicana. El indigenismo era una forma de racismo anti-español, vinculado al comunismo internacional. Aunque las atrocidades cometidas contra los indios en América después de la independencia de los países ameriçanos dejaban "chica la leyenda negra de la colonización española [...], la exaltación del indio ha llegado [alli] hasta el planteamiento de un nuevo racismo o de un racismo más [...], el mismo gran error que el nazismo". Para Pérez de Barradas, la integración del indio en el mundo occidental era un proceso inexorable; mientras no culminara, "el indio, en el ambiente político americano, aparece como un resentido y como un elemento valioso para la lucha de clases, por lo cual socialistas y comunistas tratan de atraerlo a su cam-

47 P. Constantino Bayle, S. I., El Protector..., pp. 28, 34-36, 68.

48 P. Constantino Bayle, S. I., El Protector..., pp. 8-104.

49 P. Constantino Bayle, S. I., El Protector..., pp. 160-162.

50 P. Constantino Bayle, S. I., El Protector..., pp. 1-8, 143, 147, 158.

51 José PÉrez De BarRadas, Los mestizos..., pp. 49-69, 71-76, 138, 142. 
po". Puso como ejemplo la demagogia del A.P.R.A en Perú ${ }^{52}$, escribiendo que "el aprismo es comunistoide", y que "la idea de que el ayllu es una 'forma comunista autóctona' es una fantasía intencionada políticamente, ${ }^{53}$.

A diferencia de lo que escribiera en su Manual de antropología, Pérez de Barradas ya no pensaba que el mestizaje causara la degeneración de las razas, sin duda por influencia del desenlace de la Segunda Guerra Mundial. Ahora opinaba que el mestizaje era un poderoso factor de revitalización genética, y como tal permitía valorar la experiencia española en América desde otra perspectiva, pues los españoles nunca habían sido racistas. Opinó que el racismo era "una auténtica herejía religiosa, política y científican, y justificó su nueva opinión sobre el mestizaje en la de Gregorio Marañón, autor del prólogo a Los mestizos de América, en el que se lee: "la raza estricta da los frutos humanos más excelsos, pero es a costa de su propia vitalidad. En cuanto la raza no varía, está perdida y acaba por morir [...]. Un principio axiomático en biología es que, en lo que vive, la fijación es el principio del fin [...]. La impureza étnica ha de ser considerada, por lo tanto, como un principio de estabilidad, y a la larga, de progreso material y moral, ${ }^{54}$.

Para Pérez de Barradas, el mestizaje en América explicaba la caída demográfica de la población aborigen después de la Conquista, mejor que la brutalidad de los conquistadores. Otras razones de peso habrían sido las epidemias y las guerras entre españoles. En todo caso, las estimaciones de Ángel Rosenblat de la población indígena en el Continente en 1492 -13.385.000 personas ${ }^{55}$ - probaban que se había exagerado mucho la magnitud del descenso demográfico producido después de esa fecha. En cuanto a las duras condiciones de los indígenas en el trabajo, éstas venían impuestas por las circunstancias; el trabajo tenían que hacerlo necesariamente ellos, no los españoles, pues "el descubrimiento, la conquista

52 El A.P.R.A., Alianza Popular Revolucionaria Americana, era un movimiento indigenista anti-estadounidense y panamericano fundado en el Méjico revolucionario por el peruano Víctor Raúl Haya de la Torre. La sección peruana del movimiento, el Partido Aprista Peruano, fue muy activa en los años 30 y 40; véase Adam ANDERLE, Los movimientos políticos en el Perú entre las dos guerras mundiales. (La Habana: Casa de las Américas, 1985), pp. 99-114, 155-367.

53 José PÉrez de BARRADAs, Los mestizos..., pp. 195-203. El ayllu era la unidad social básica en la organización indígena de los Andes Centrales. Los indigenistas peruanos la entendían como un clan, y el fundamento de un socialismo o comunismo avant la lettre que habría existido en los Andes antes de la llegada de los españoles.

54 Gregorio MaRAÑón, "Prólogo", a Los mestizos de América, pp. xiv-xv.

55 Ángel RosenBlat, La población indigena de América desde 1492 basta la actualidad (Buenos Aires, 1945). 
y la organización de la colonia necesitaba el esfuerzo de sus cabezas para pensar y el de sus brazos para defender con la espada lo ganado" ${ }^{56}$.

El mestizaje, además, explicaba el éxito de las campañas de conquista, al revelar la complicidad de las mujeres indias con los españoles. Las uniones con estas mujeres fueron en su mayoría voluntarias, como consecuencia de la atracción física por los recién llegados - los indios eran malos amantes, además de tristes, borrachos y holgazanes- y por efecto del régimen de matriarcado en algunas zonas, que Pérez de Barradas concebía como el de las amazonas de la mitología clásica ${ }^{57}$.

En sus artículos de 1951, Comas acusó al P. Bayle y a Pérez de Barradas de racismo, a pesar del cambio de opinión de éste con respecto al mestizaje. Según él, los estudios de ambos denigraban al indio y a lo indio, falseaban los hechos de la Conquista y la Colonización y atacaban injustamente a Bartolomé de Las Casas y al indigenismo. Comas empezó enumerando los logros de las culturas aborígenes, que tanto Bayle como Pérez de Barradas habían decidido ignorar. Fiel al esquema evolucionista, Comas advirtió que en el Nuevo Continente había habido "dos niveles de civilización totalmente distintos": el de "culturas muy primitivas" en las regiones extremas boreal y austral, y el de "las altas civilizaciones" de "lo que podría llamarse América intertropical. Los logros que Comas mencionaba - en la metalurgia, la medicina, los tejidos, la ingeniería agrícola, las bellas artes- correspondían a esas "altas civilizaciones". Era cierto lo de las borracheras y el consumo de estupefacientes como la coca, pero eran vicios que habían estado poco difundidos antes de la Conquista. No eran connaturales a los indios. En la actualidad no se daban en mayor grado que entre otras poblaciones del continente. Indicaban sobre todo las míseras condiciones en que los indios habían vivido durante la época colonial y en que vivían en el presente ${ }^{58}$.

\footnotetext{
56 José PÉrez dE BARRAdAs, los mestizos..., p. 138.
}

57 José PÉREZ DE BARRADAS, Los mestizos..., pp. 76-89. La única prueba que ofrecía el autor de tal régimen de matriarcado era la existencia del intercambio de hermanas entre clanes matrilineales, y el papel destacado en ellos del hermano de la madre; como en la obra de Pedro DE AGUADo sobre los pantagoras, Historia de la provincia de Santa Marta y del Nuevo Reino de Granada (Madrid: Espasa-Calpe, 1931). Hacía ya décadas que la antropología había negado toda veracidad histórica o etnográfica al matriarcado en el sentido en que lo entendía Pérez de Barradas.

58 Juan ComAS, "Reivindicación...”, pp. 130-142. Hoy, lejos ya de los presupuestos evolucionistas de la época, se entiende que las llamadas «borracheras de los indios eran parte de sus ritos de reciprocidad y afirmación comunitaria, y que el consumo de estupefacientes como la coca, aparte sus virtudes terapéuticas en condiciones duras de trabajo como las apuntadas por Comas, eran elementos fundamentales en com- 
El mestizaje había tenido lugar, en efecto; pero esto significaba ante todo el surgimiento de una "cultura mestiza". La prueba más visible de ello era el sincretismo religioso. Pérez de Barradas había exagerado el éxito de la evangelización, al ignorar que muchos frailes y sacerdotes fueron culpables de abusos contra los indígenas y que los esfuerzos educadores de otros, con el apoyo de la Corona, se vieron obstaculizados por las autoridades civiles. Comas no protestaba contra la evangelización por principio; al contrario: concebía la evangelización como un medio de aculturación, y lamentaba sus pobres resultados ${ }^{59}$. Para él, no obstante el esplendoroso desarrollo cultural aborigen, la subsiguiente fase europea había representado una etapa evolutiva superior. La diferencia con el P. Bayle y Pérez de Barradas radicaba en la distinta valoración del pasado indígena.

Del mismo modo, el espíritu protector de las leyes de Indias y de instituciones como el Protector de Indios, no negadas por Comas, no contradecía para éste los múltiples casos de abusos cometidos contra los indígenas, con ocasión de la Conquista y después de ella. Paradójicamente, buena parte de la documentación que aducía provenía de denuncias ante las autoridades coloniales ${ }^{60}$, lo que hacía resaltar el papel tutelar de éstas que ya habían destacado el P. Bayle y Pérez de Barradas. Por otro lado, Comas no puso en entredicho las estimaciones dadas por Ángel Rosemblat sobre la caída demográfica indígena después de 1492, que Pérez de Barradas había aceptado. La discrepancia sobre los abusos era más bien de perspectiva: si se aceptaba la norma o las violaciones a la norma como criterio valorativo de la experiencia española en América.

Estos puntos en común remitían de nuevo al nacionalismo de unos y otros y a la naturaleza en el fondo política de la disputa. Comas rechazó enérgicamente la acusación de que la exaltación de lo indígena y la crítica de la Conquista y la Colonización implicaban anti-españolismo. Explicó que tampoco él creía en el mito del buen salvaje, y que sabía valorar los elementos positivos de la cultura occidental aportados por los españoles. Escribió que España podía presumir —en comparación con otros

plejos rituales mágicos y religiosos; véase, por ejemplo, John MURRA, La organización económica del Estado inka (México, D. F.: Siglo XXI Editores, 1978), traducción de Daniel R. Wagner, pp. 62-64, 137-142, 178; y Visita de los valles de Sonqo en los yunka de coca de La Paz (1568-1570) (Madrid: Instituto de Cooperación Iberoamericana, Sociedad Estatal Quinto Centenario e Instituto de Estudios Fiscales, 1991).

59. Juan Comas, "Reivindicación...", p. 143; "La 'cristianización' y 'educación'...", pp. 220-232.

60 Juan ComAs, "La realidad del trato...", pp. 339-346. 
países con experiencias coloniales - de esa aportación, además de por tener en su historia a personajes como Bartolomé de Las Casas, Francisco de Vitoria, Antonio Montesinos y muchos otros que denunciaron los actos de violencia cometidos contra los indios; como había puesto de manifiesto Lewis Hanke ${ }^{61}$. $\mathrm{Y}$ estuvo de acuerdo en que esos actos no desaparecieron con la independencia de los países iberoamericanos. "La civilización hispánica en América -escribió- tuvo un gran poder de autocrítrica, libertad ideológica y de expresión que en otros países no podía soñarse siquiera. En realidad España puede enorgullecerse de haber tolerado y estimulado incluso en América este espíritu de criticismo [...]. El gran hispanista L. Hanke reitera: 'es eterna gloria de España haber permitido que unos hombres insistieran en que todas las acciones de España en América fueren justas, y el haber escuchado sus voces en ocasiones'" ${ }^{62}$.

\section{POLÍTICA INDIGENISTA E INDIGENISMO POLÍTICO}

Pérez de Barradas y Manuel Ballesteros Gaibrois, catedrático de Historia de América Prehispánica en la Universidad de Madrid ${ }^{63}$, contestaron a Comas en sendos artículos publicados ese mismo año, $1951^{64}$. Ballesteros fue el primero, arremetiendo contra "el tono que los trabajos indigenistas adoptan, tono áspero, resentido, de sublevación demagógica, sin que queden claros los fines que puedan perseguirse con tales posturas, que al ser hipercríticas con el pasado - y casi nunca con el presente-, más destruyen que edifican" 65 .

Advirtió que Comas no estaba en contra de la evangelización, considerando entonces impropio de un "escritor de las letras y lecturas de Comas, que roza con sus trabajos temas de la Historia de la Cultura", que se sorprendiera de las pervivencias de las religiones prehispánicas. Explicó que lo sorprendente hubiera sido lo contrario, pasando por alto que

${ }^{61}$ La lucha española por la justicia en la conquista de América (Buenos Aires: Editorial Suramericana, 1949).

62 Juan Comas, "Reivindicación...", p. 143; "La realidad del trato...", pp. 339, 368.

63 Había ganado la cátedra en 1950. Unos años más tarde, entre 1960 y 1963 , sería gobernador civil de la provincia de Tenerife: Carmen ORTIZ y Luis Ángel SÁNCHEZ GÓMEZ (eds.), Diccionario..., op. cit., p. 130.

64 José PÉREZ DE BARRADAS, "El indigenismo político y la actuación de España en Américan, Antropología y Etnología, 4 (1951), pp. 115-133. Manuel Ballesteros GaIBroIs, "El americanismo en las revistas", Revista de Indias, 45 (1951), pp. 599-643.

65 "El americanismo...", p. 608. 
Pérez de Barradas había planteado precisamente esto último. Comas era "acientífico y tendencioso [...]; acientífico porque hace un alegato de fiscal y no un juicio de historiador [...]; tendencioso [...] porque actúa sobre un parti pris y todo lo pliega a él. Recurrió entonces a las ya familiares comparaciones, a pesar de que Comas también las había hecho:

No creo que el señor Comas sea tan ingenuo que crea que los blancos de las naciones americanas de hoy son más humanos —en el sentido de humanitariosque los colonizadores, o menos humanos - en el sentido de las debilidades del hombre- que los 'explotadores' coloniales, y que el apetito del caucho o del petróleo, o de las minas, o simplemente de la utilización del trabajo ajeno, se halle hoy más adormecido que hace dos siglos ${ }^{66}$.

La política española en América había que enjuiciarla por sus propósitos y su legislación, como ya habían hecho el P. Bayle y Pérez de Barradas; pues en la historia siempre ha habido maldad, "ya fuera en la Hispania antigua bajo Roma, o en Pataliputra con los ingleses, o en el Senegal y la Guayana por los franceses. El hombre es -ya lo dijo Hobbes- 'homini lupus'. Comas había sido "voluntariamente ignorante" por no recordarlo. $\mathrm{Y}$ Ballesteros se preguntaba: " $\mathrm{H} H \mathrm{Ha}$ hecho el indigenismo hasta ahora, en sus declaraciones solemnes y sus estudios, otra cosa que seguir el camino de los propósitos, representado por las leyes de Indias? Realmente no" ${ }^{67}$.

Pérez de Barradas argumentó que Comas no había rechazado la tesis principal de Los mestizos de América: la de que los españoles no habían sido racistas en América, y que el resultado de ello había sido el mestizaje. Haciéndose también eco de la obra de Lewis Hanke, llamó la atención sobre que a Comas le parecieran "excelentes" las leyes de Indias y reconociera que la situación no había cambiado después de la independencia de las colonias. Estuvo de acuerdo con Ballesteros en que hubiera sido ingenuo esperar que la evangelización llegara a completarse; de todos modos, dijo, "la conquista espiritual de América" podía darse por hecha, "puesto que no persisten en ella religiones indígenas organizadas con culto y millares de fieles, como sucede en la India, por ejemplo" ${ }^{68}$.

Con respecto a la acusación de que había despreciado el desarrollo cultural aborigen, y que eso implicaba racismo, la consideró ofensiva. Alegó en su favor sus trabajos sobre la Colombia indígena, ignorando el hecho de que Comas se había referido a su Manual de antropología y a Los

\footnotetext{
66 "El americanismo...", pp. 608, 610.

67 "El americanismo...”, pp. 610, 611.

68 „El indigenismo político...", p. 127.
} 
mestizos, así como a El Protector de Indios, del P. Bayle. En 1492 había, en efecto - contestó Pérez de Barradas-, zonas de "alta" cultura y otras de "baja" cultura en América; no obstante, el estadio de mayor avance alcanzado en organización económica y medios técnicos había sido muy inferior al de los españoles del siglo XVI. Pérez de Barradas insistió además en lo de las borracheras y el consumo de estupefacientes ${ }^{69}$; y en que los indios eran "perezosos", aunque podía entender que fuera por una cultura distinta del trabajo. Pero, en resumidas cuentas, "O el Nuevo Mundo permanecía salvaje o era necesario obligar a trabajar a los indios, a los que, por otra parte, había que educar, doctrinar y civilizar de grado o por fuerza" ${ }^{70}$.

Asimismo, Pérez de Barradas abundó en la argumentación de Ballesteros contra el indigenismo, haciendo hincapié en que Comas era secretario del Instituto Indigenista Interamericano y director del Boletín Bibliográfico de Antropología Americana. Distinguió así entre "política indigenista" e "indigenismo político". Lo primero, que él apoyaba, era la "empresa política de mejorar la situación de treinta millones de seres humanos, de darles un más alto nivel de vida, una alimentación eficiente, vida sana e higiénica, medicamentos y dispensarios, así como cultura, en el más amplio sentido de la palabra". Pero el "indigenismo político" era algo muy distinto: "unas veces toma como bandera la postura antiespañola y anticlerical y otras veces se convierte en plataforma electoral de partido [...]. Trata de centrar al indio y lo indio como elemento fundamental de las nacionalidades americanas, para lo cual pone, absurdamente, frente a frente al indigenismo y al hispanismo, como si fueran fuerzas e ideas antagónicas [...]. Esto está tan mal planteado como si en España se hablara de celtiberismo contra romanismo y, añadimos nosotros, como si aún lanzáramos anatemas contra las crueldades y destrucciones originadas por la conquista romana, que mató en flor la cultura celtibérica y que torció los destinos de España" ${ }^{71}$.

Comas replicó a Pérez de Barradas, no a Ballesteros, el año siguiente, en un artículo publicado en la Revista de Indias ${ }^{72}$. Consideró irónico que hablara de indigenismo alguien que en Los mestizos de América había escrito frases como las siguientes: "El indígena acudía a los estupefacien-

69 En 1950 había publicado su largo artículo "Drogas ilusionógenas en los indios americanos", op. cit..

70 "El indigenismo político...", p. 129.

71 "El indigenismo político...", pp. 132-133.

72 "El indigenismo de J. Pérez de Barradas", Revista de Indias, 49 (1952), pp. $547-$ 562. Ballesteros ofreció a Comas las páginas de esta publicación para su réplica. 
tes para suplir su complejo de inferioridad" ${ }^{73}$, "El mestizo se arrimaba al más noble de los padres", entendiendo por tal al español ${ }^{74}$, "La posición económica del negro era mejor que la del indio, puesto que era más inteligente, más hábil, más trabajador" 75 , "El indio americano es por naturaleza triste, pero no ahora, vencido y derrotado, [sino] en sus mejores épocas y en las culturas más florecientes. Véase, si no, el arte maya. Nada hay más casto, ni una figura femenina, ni una escena de sexualidad" ${ }^{76}$. Estas y otras frases contradecían las manifestaciones de antiracismo de su autor en la misma obra. Según Comas, Pérez de Barradas había derivado gratuitamente caracteres psicológicos y de personalidad de las peculiaridades raciales indígenas.

Con respecto a la tesis central de Los mestizos de América, Comas escribió que no había encontrado ninguna a la que contradecir:

¿Trata, acaso, de demostrar que los españoles de los siglos XV y XVI no tuvieron prejuicios raciales y se mestizaron rápidamente con los indígenas? [...] ¿ O quiere únicamente hacer la defensa de la lesgislación indianista? [...] ¿ $\mathrm{O}$ pretende justificar gran parte de las tropelías cometidas por los conquistadores y colonizadores, pese a las leyes establecidas y a las sabias orientaciones del Consejo de Indias y de la Corona de España? [...] ¿Persigue, quizá, como objetivo denigrar con verdaderos insultos a fray Bartolomé de Las Casas, tildándolo de libelista, antiespañol, mal intencionado, liviano, de poca autoridad, mentiroso, sádico en sus escritos, psicológicamente anormal, calumniador, falsario, dignas sus obras 'de ser quemadas por mano de verdugo', etc.? [...] ¿Es, acaso, su objetivo tergiversar los fines del movimiento indigenista contemporáneo, al cual achaca entre otras muchas cosas, 'negar los orígenes españoles', lo considera 'el mismo gran error que el nazismo' y lo acusa de que 'ha pretendido borrar la obra de España? [...]. No; [...] Los mestizos de América [es] [...] simple y sencillamente [...] un conglomerado de capítulos [...] que discuten temas distintos, con fines distintos, a veces relacionados y otras independientes...

El año siguiente, Comas respondió en detalle a los ataques al indigenismo en un nuevo artículo para América Indigena ${ }^{77}$. Explicó que el indigenismo era un movimiento respetable, avalado por una organización -el Instituto Indigenista Interamericano- en la que participaban quince países. Ya hacía tiempo que el indigenismo no era "lírico y sentimen-

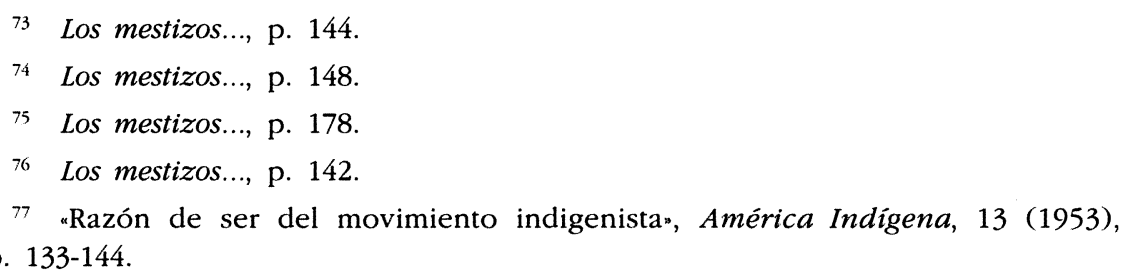
pp. 133-144. 
tal"; aunque tampoco tenía "una orientación 'humanitaria' [...] ni de beneficiencia", sino "de justicia social", de "reivindicación" ${ }^{78}$. Lo que no significaba que buscara la proletarización del indio, y menos que fuera comunista, como había aseverado Pérez de Barradas. Alegó que "militan como elementos activos en el campo del indigenismo millares de prestigiosas personalidades (científicas y políticas) que en sus respectivos países sustentan ideologías y creencias muy distintas"; lo que era cierto, y entre ellas había socialistas y comunistas, que Comas no mencionó, tal vez por prudencia ante el desenvolvimiento de la Guerra Fría en esos años ${ }^{79}$.

Fuera sincera o no esa desvinculación con el socialismo o el comunismo, Comas abogaba abiertamente por un indigenismo social y políticamente muy activo, que contrastaba con el laissez faire preconizado por Pérez de Barradas y que por ello se ajustaba en buena medida a lo que éste había denunciado en Los mestizos de América. La posición de Comas en este punto era coherente con la defensa que había hecho en 1951 de la evangelización como medio de aculturación. Señaló que las medidas tomadas por algunos gobiernos en el terreno socioeconómico, sanitario y educativo no habían sido suficientes para sacar al indio de su postración. Había que atender "al factor cultural":

Muchos de los rasgos culturales de 'tipo occidental' que deben sustituir a los que actualmente tienen los indígenas (por ejemplo, los de tipo sanitario y de prácticas agrícolas, por lo menos parcialmente) no podrán jamás implantarse con éxito si previamente no se conocen a fondo los modos de pensar y obrar de dichos aborígenes sobre el punto de que se trate; y si no se logra además, con una labor que compete primordialmente al antropólogo social, un previo cambio de actitud mental ${ }^{80}$.

Sobre esa base, el éxito de los planes reformistas estarían asegurados: el indigenismo no deseaba la "asimilación ni absorción" de la cultura indígena en la occidental,

sino que aspira - con gran espíritu de justicia - a que la aculturación o transculturación de los grupos aborígenes se haga parcialmente de forma que sean sustituidos todos aquellos rasgos o caracteres nocivos y perjudiciales; pero en cambio lucha por conservar, incrementar, mejorar y enriquecer otros rasgos de los que

78 «Razón de ser...", p. 137

79 Por ejemplo, en Perú, socialistas o comunistas interesados o vinculados con el indigenismo fueron José Carlos Mariátegui e Hildebrando Castro Pozo; en Méjico, Miguel Othón de Mendizábal y Luis Chávez Orozco.

80 «Razón de ser...", p. 136 
los indígenas pueden sentirse orgullosos: el arte en sus múltiples manifestaciones (lacas, cerámicas, tejidos, etc.), las pequeñas artesanías domésticas, el sentido de respeto y reconocimiento hacia sus propios gobernantes, el espíritu cooperativo y de comunidad en el trabajo, el sentido moral, etc. [...] El indigenismo no quiere repetimos- 'desindianizar' a los indios; quiere simplemente dotarlos social, cultural y económicamente de los medios más adecuados a su mejor desenvolvimiento, pero respetando cuantas manifestaciones materiales o psíquicas, incluso el idioma [...], de su cultura materna se consideran útiles y dignas de ser impulsadas ${ }^{81}$.

Ante la crítica de que tal proyecto de integración nacional causaría inadvertidamente una pérdida de las señas de identidad indígenas, empezando por la lengua, Comas respondió poniendo el ejemplo de España y otros países europeos, a los que consideraba como el modelo de integración para los países iberoamericanos: "hace siglos que existen naciones como Francia, Bélgica, España, en las que subsisten con vida propia, idiomas como el wallon, el bretón, el vascuence, el catalán, el gallego, etc., junto a los idiomas nacionales. ¿Por qué, pues, pensar que deben extinguirse, por ejemplo, el quechua, el maya, el otomí, el náhuatl o el cakchikel hablados por centenares de miles de individuos y algunos de ellos con literatura propia?" 82 .

Pérez de Barradas no contestó. Ese artículo de Comas de 1953 fue el último acto del debate. Pérez de Barradas había dejado de ser director del Museo Etnológico y poco después su carrera empezaría a eclipsarse, como también el papel del Instituto Bernardino de Sahagún. El Instituto perdió sus secciones de Valladolid y Barcelona en los años siguientes, y en 1961 dejó de publicarse su principal órgano de difusión, la revista Antropología y Etnologia ${ }^{83}$.

Por el contrario, la carrera de Comas continuó en ascenso. En 1955 ingresó en la Universidad Nacional Autónoma de México, donde dirigiría la sección de antropología del Instituto de Investigaciones Históricas hasta prácticamente su jubilación en 1975. Trabajó en varios proyectos para la UNESCO sobre los prejuicios raciales, y en 1960 fue nombrado vicepresidente del Comité Internacional para la Estandarización de las Medidas Antropológicas ${ }^{84}$.

81 "Razón de ser...", p. 138. En su carta a Luis de Hoyos de 3 de abril de 1950, Comas había sido aún más contundente, si cabe: "América es un producto de mestizaje no sólo racial sino cultural y [...] hay muchas cosas que deben aprovecharse y aun incrementarse procedentes de las culturas precolombinas, en tanto que otras muchas deben desterrarse y ser sustituidas realmente por las de cultura european.

82 "Razón de ser...", pp. 139-140.

83 Luis Ángel SÁNCHEZ GómEZ, "La antropología...", op. cit., p. 31 y ss.

84 Carmen Ortiz y Luis Ángel SánChez GÓmez (eds.), Diccionario..., op. cit., pp. 209-212. 


\section{CONCLUSIONES}

Con el lenguaje de la antropología americanista de los años 40 y 50 , Comas y Pérez de Barradas - y con éste Ballesteros- enriquecieron la controversia moderna sobre España que había empezado en el siglo XIX; y contribuyeron de paso a mantenerla viva: el primero desde su influyente posición internacional como secretario del Instituto Indigenista Interamericano, y los demás desde importantes posiciones académicas en la España de Franco.

Aunque no tenía por qué ser necesariamente así —al tratarse de hechos objetivamente lejanos-, la imagen histórica de España como nación estuvo muy presente en sus opiniones científicas sobre la Conquista. Los tres compartían el credo evolucionista que clasificaba a las sociedades por el grado de desarrollo de sus conocimientos técnicos, de sus instituciones y de su producción intelectual; lo que permitía considerar el periodo de dominación española en América como un estadio de civilización superior al alcanzado por las formas culturales aborígenes. Por otro lado, como también resaltaron los tres -y Comas y Pérez de Barradas citando orgullosos a Hanke-, ese periodo arrojaba un balance positivo si se le comparaba con el de otras potencias coloniales, o con la historia de los países iberoamericanos después de su independencia. La legislación de la Corona española, la evangelización y las instituciones de protección de los indígenas eran lo que daba contenido a ese balance favorable.

Las discrepancias remitían directamente al debate nacional. Para Pérez de Barradas, la Conquista y la Colonización habían sido necesarias para el bien de los indios y gloriosas para España. El testimonio más visible y duradero de la empresa era la mezcla de razas y el progreso material y espiritual que acompañó a la Colonización. Los casos de violencia contra la población nativa fueron inevitables, pero pocos de ellos quedaron impunes; la leve caída demográfica de esta población después de 1492 no podía atribuirse claramente a la violencia de los conquistadores ni a los efectos de la Colonización, sino a otras razones, como epidemias y el mismo mestizaje con los recién llegados. Quienes opinaban lo contrario, como Bartolomé de Las Casas en el siglo XVI o los indigenistas en el XX, eran testigos de poca credibilidad o enemigos de España. Los indios eran claramente inferiores a los españoles, como lo son hoy ante los blancos y mestizos de Iberoamérica; están condenados a desaparecer ante el empuje de la cultura occidental.

Para Comas, por el contrario, la Conquista y la Colonización dieron lugar a múltiples actos de violencia, sólo parcialmente paliados por la le- 
gislación de la Corona, las instituciones judiciales y la evangelización, que fue lo que realmente podía facilitar de manera pacífica el paso de la población aborigen a una forma de cultura superior. Fue también éste el principal factor del mestizaje cultural, de mayor magnitud y consecuencias que el biológico. Las culturas aborígenes eran inferiores a la española del siglo Xvi, pero sólo en términos relativos, como prueban los restos materiales dejados por las grandes civilizaciones precolombinas y los testimonios de aquellos que las admiraron, entre ellos Bartolomé de Las Casas. Éste era tan español como los conquistadores. En cuanto a los indigenistas, no eran enemigos de España, sino modernos protectores de los indios; luchaban por una asimilación controlada que les condujera a su integración como ciudadanos de países étnica y culturalmente heterogéneos, como España, donde la unidad política se había impuesto sobre la "variedad morfológica" de la población.

Comas reivindicaba la España reflexiva, tolerante y políticamente plural que en el siglo xIx habían defendido Juan Antonio Llorente y Luis Morote: la España "liberal", en la terminología de Fox. Pérez de Barradas reivindicaba la España heroica, afirmativa y uniforme de nacionalistas católicos como Maeztu y Menéndez y Pelayo, aunque también de autores ajenos a esta tradición, como Menéndez Pidal y Ortega y Gasset, también "liberales" en la definición de Fox.

Aunque, por razones coyunturales, la controversia ocasionada por los actos conmemorativos del V Centenario del 12 de octubre de 1492 no puede considerarse una reproducción del debate que enfrentó a Comas y Pérez de Barradas entre 1949 y 1953 - ni tampoco éste una reproducción de polémicas anteriores-, hay sin embargo suficientes elementos en común de una a otra coyuntura como para que pueda hablarse de continuidad. El primero de ellos es el mismo planteamiento de la identidad nacional de España, hecho en los años de lucha contra el Antiguo Régimen, como también tras la crisis de 1898 y los sucesos de la Semana Trágica, en los años de creación doctrinal de la dictadura de Franco o con ocasión del centenario de 1492, por mencionar sólo aquellas coyunturas que han favorecido la polémica sobre el valor que tiene la Conquista de América para esa identidad.

Hay además suficientes lugares comunes en las discusiones. Igual que la idea de España de Comas recuerda al federalismo de Luis Morote -aunque éste tuviera una idea gloriosa de los hechos de los conquistadores-, su indigenismo anticipa el de Subirats en la controversia sobre el V Centenario, si bien Subirats es crítico con Las Casas, mientras que Comas lo elogiaba. En el otro extremo, la refutación de la teoría del genocidio hecha por Pérez de Barradas recuerda los ataques de Juderías 
contra la leyenda negra, hechos en otro contexto. Por otro lado, la obra de Pérez de Barradas es precursora de la de Beceiro García, aunque éste no comparta las obsesiones sobre la eugenesia y el mestizaje biológico de aquél. Otros elementos de continuidad son las referencias a la violencia de los conquistadores, sustentadas en lo dejado escrito por los mismos españoles, como Las Casas; o la comparación con lo hecho por otras potencias coloniales en sus respectivos dominios; o el elogio de la legislación pro-indígena de la Corona y ciertos aspectos de la Colonización - también la idea del mestizaje cultural- como medio de salvaguardar la imagen histórica de España y destacar su contribución al progreso cultural de la humanidad.

La controversia tiene, pues, una larga historia, que hay que añadir a la de otras controversias que intervienen en la discusión sobre la identidad nacional. No hay aquí una historia canonizada. En este terreno del nacionalismo, tal vez sea eso lo que distingue más a España en comparación con otros países, como por ejemplo la Francia republicana: el debate recurrente sobre lo que es y debe ser políticamente.

JUAN J. R. VILLARÍAS ROBLES Departamento de Antropología, CSIC

Entre 1949 y 1953, dos antropólogos americanistas españoles afectados por la guerra civil debatieron acerca de la conquista de América y sus consecuencias. La discusión era también sobre la identidad nacional de España, al versar sobre uno de los fundamentos históricos sobre los que esta identidad quería sustentarse. Con el lenguage de la antropología de la época, Juan Comas y José Pérez de Barradas contribuyeron a un debate que había empezado en el siglo XIX, y que ha reverdecido en los últimos años con motivo de la conmemoración del V Centenario del descubrimiento colombino. Como las historias nacionalistas del País Vasco y Cataluña, el controvertido tema de la conquista de América dificulta la construcción de la identidad de España como nación.

Between 1949 and 1953, two Spanish americanists affected by the civil war debated on the conquest of America and its consequences. The discussion was also on Spain's national identity, since it concerned a basic historical tenet on which such identity was to be constructed. With the anthropological idiom of the times, Juan Comas and José Pérez de Barradas helped to maintain a controversy that had originated in the 19th century, and has been rekindled in recent years by the Spanish government's celebrations of the 500th anniversary of Columbus' first voyage to the Americas. Like the nationalistic histories of Catalonia and the Basque Country, the controversial subject of the Conquest still precludes the consensus needed behind the idea that Spain is a nation. 